\title{
The Construction of Setting Traditional Culture as Core Curriculum of Business English
}

\author{
Yuhuan Zhang ${ }^{1, a^{*}}$ \\ ${ }^{1}$ School of Foreign Languages, China West Normal University, China No. 1 Shi Da Road, Shunqing \\ District, Nanchong, 637009, Sichuan, China \\ ajuliezhyh@163.com
}

Keywords: Business English; Traditional culture; Core curriculum; English teaching

\begin{abstract}
Business English is an emerging and rapidly developing interdisciplinary based on foreign language and literature, economics, law and management science etc. and the feature specialty which requires majors to master language knowledge, business knowledge, cross-cultural knowledge, knowledge of humanities and social sciences and interdisciplinary knowledge. This paper does cross-cultural knowledge as the breakthrough point and analyzes the setting of core curriculum for business English majors and combines with business English professional training target of China, present reality of students' learning English of business and trade. It comes to a conclusion that the effect of the local traditional culture on business English majors' cross-cultural communication ability training cannot be ignored. Moreover, it presents that the traditional culture seeks the balance among society, students and teachers, which can bring brilliant shine to business English teaching.
\end{abstract}

\section{Introduction}

It is acknowledged that great changes have taken place in our times and are evolving at the incredible speed. The fast development of economic globalization and cultural diversity make the international communication becomes increasingly frequent: people from different cultural backgrounds have more close contacts; the flow of trade between China and other countries has a permanent basis. With the wide-spread application of information technology represented by computer technology and modern communications technology, human beings have entered the digital information age in which technology breaks through the limitations of time and space and makes it more convenient among countries to make deals. It is obvious that cross-cultural communication has become the universal fact. English, as a communication tool among international business and trade entities, highlights its importance. More and more lofty ideals of youth set on their lofty business English ambition, which provides the guarantee of talents who serve bilateral trade between China and other countries. With the purpose of making business English graduates be capable of joining in trade activity to produce economic benefits in a short time and shorten the time of internship in companies, curriculum setting for business English majors during the period of , university, especially core curriculum setting, have some special requirements.

\section{Related Definition}

The concept of core curriculum originated in late 19th century and early 20th century,with the German educator T. Ziller's "Ziller plan" and American educator F. Parker's "Parker plan" as the symbol.[1] Core curriculum, from the etymological point of view, its "core" comes from Latin word "cor", with the meaning of "heart". Curriculum expert Bart Vik has written down the sentence: heart, place of life origin and part of body, spreads the nutrition of life. [2] According to etymology and the importance of heart described above, core curriculum should not only be located in the central position of the whole course system but also have generative power. After two centuries of transitions, great changes have taken place in core curriculum: society-oriented core curriculum outlook, experience-oriented core curriculum outlook, subject-oriented core curriculum outlook and 
hybrid-oriented core curriculum outlook. This paper has the adoption of the fourth one. Core curriculum cannot be simply understood as some compulsory subjects but a hybrid curriculum construction which can meet the needs of students and society. Besides, it can seek a balance among students, subjects and society, effectively unifying them. However, because of the baton of college entrance examination, the reality of our country is that Chinese, math and English establish their own strong trend status and certainly become core curriculum in the whole course system. As a matter of fact, researches on core curriculum are abundant but they are based on a certain subject, such as the construction of professional sports course system and the construction of education course system in primary school...; or they put the learning course system in a certain stage as the reference point, such as the construction of politics course system in middle school and the exploration to general education curriculum in universities.... But in our country, business English is a new and developing specialty; therefore there is no ready-made experience to draw from. Nowadays, in some colleges, their business English has not become a whole course system; they just have explored a suitable way in reality; therefore, the material of business English research is so limited. Given this, the author puts forward some suggestions on the basis of its own business English teaching practice.

\section{The Necessity of Setting Traditional Culture as Core Curriculum}

The national standard of undergraduate business English points out explicitly that business English aims to cultivate compound and applied talents, with language basic skills, international vision, humanity accomplishment; mastering relating basic theory and knowledge on linguistics, economics, management, law(international commercial law);being familiar with the rules and practices of international business and trade; with English applied ability, business practical ability, cross-cultural communication ability, innovation ability and autonomous learning ability.[4] Meanwhile, it further indicates that business English majors should have five competences: ideal competence, cultural competence, professional competence and psychosomatic competence. [5] It is easy to see that business English majors must be qualified for internal cultivation of culture; in other words, they have to know Chinese culture and western culture. If business English majors want to effect real cross-cultural communication, they should not only be equipped with basic knowledge of English, theoretical and practical knowledge of business but also Chinese culture. The real cross-cultural communication is a two-way communication on the basis of equal dialogue. Both cultures of cross-cultural communication have mutual communication and influence and both sides respect the others' special culture; as a result, that can help to achieve cross-country trade.

For most of business English undergraduates at present, KFC, Co cola and other western food, Halloween, Christmas and other western traditional festivals dip-dye their life everywhere. World multi-polarization, especially the United States, as the representative of western strong culture has the delusion of controlling ideology and has given Chinese traditional culture profound impact; besides, the strength of the Korean culture infiltration, our national culture suffered from serious challenges. The media and dealers, at the coming of each western festival, go wild with these festivals; as a result, more and more Chinese people worship everything foreign and manage to accept the western festivals. On the contrary, our own traditional festivals are becoming more and more deserted and more youths disregard those. In the stage of cross-cultural communication, Chinese culture has to comply with western culture, which causes to inequality of international trade and negotiation.

There is a solid foundation for the relationship between China and other countries, with extensive co-operations in various fields and more perfect layout of bilateral and multilateral business trade. Up to now, our country has reached 14 free-trade agreements, including twenty-two countries and areas in Asia, Latin America, Oceania and Europe. China continues to strengthen economic, trade and investment cooperation with the United States, the European Union and the main countries of Asia, Africa and Latin America; the belt and road initiative is deepened; it comes out that our country would enjoy great potential and vast develop prospects in field of foreign trade's continuous development.[3] Good national policies and expansion in terms of investment and 
trade need more business English talents; meanwhile, that sets forward higher requirements: they not only are perfectly familiar with Chinese culture but also have a good knowledge of western strong culture, with the United States as the representative, and understand rich ethnic culture of Asia, Africa and Latin America.

The setting of our foreign language curriculum lasts longest: starting from the third grade until Doctor Degree, even that the title appraisal and promotion, etc. are inextricably linked with English, which lends to the phenomenon that Chinese people cannot give up English learning and most of them are crazy for studying English. English has being occupied the top of the priority in Chinese people's education world because of blind identification of English and official support for examinations relating with English such as CET4, CET6 and PET, etc. Much worse, teachers blindly emphasize the input of target language culture but neglect mother language input in traditional English classes. Compared with Chinese curriculum, starting from primary school until senior high school, at colleges, little trace of Chinese traditional classes still remain except the students doing Chinese classical literature and culture as their majors. Without doubt, the fault of studying Chinese culture appears at colleges. Even if some colleges set Chinese as liberal class, they put a low value on such liberal education, increasingly dispensable. It is the time for students that they reached deep inside of Chinese culture, but they cannot attend any Chinese classes. It is impossible for them to experience core value of Chinese culture. These bizarre representatives in society have forced the historical quirk_ the Chinese culture aphasia and the western culture talked with fervor and assurance.

\section{Implications for Business English Teaching}

Our country published national standards of business English in 2015. On a macro-scale, it requires that curriculum setting of business English should take cultivating students' cross-communication ability into consideration; in combination of Chinese culture aphasia, it puts more emphasis on intensifying the study of traditional culture and setting traditional culture curriculum as core course, which can be understood as attaching great attention, deepening and consolidating traditional culture study. Cultural understanding and cultural empathy are catalyst of facilitating business trade and soft power of reaching business trade. Cultural connotation is extensive: sign, language, value and code of conduct; culture can be to explore life condition from mufti-angle and multiple dimensions. Culture can be used to comprehend people's lives and helps people gain indirect experiences of lives, which come from culture study not from people's own personal getting; more important, people can be affected by various emotional contagion described in cultural contents. Setting traditional culture as core curriculum for business English should be combines with social requirements and expectation; from students' needs and interests, teachers should be equipped with Chinese and western culture on equal dialogues of cross-communication, including English language proficiency, target language culture and business knowledge.

Social Needs and Expectations. Social need and expectation are indispensable influencing factors of the core curriculum. School system is part of social system, so existing questions and expecting behaviors must be embodied in school life and curricula. Business English majors can be hoped as ones with business practical ability and English cross-communication. Speaking of cross-cultural communication, students have to have accumulation of Chinese-English culture; thus, our culture conforming to western strong culture in one-way would not happen. It is school's obligation that business English curriculum guides students into entering social business life, facing various kinds of business questions and forming their capacity of solving business problems and business emergencies in business occasions. It is obvious that society hopes that business English students have good cross-cultural communication in business areas; thus students are required to have a systemic study of Chinese traditional culture. It is necessary that traditional culture has to be studied as core curriculum in business English study. 
Students' Needs and Their Own Characteristics. Students' needs are the litmus test on whether a core curriculum is effective or not. When business English majors believe or find that traditional culture study can help them get the contents benefiting their future business activity; they approve of these culture courses and make efforts to study the contents. Colleges and teachers play an important role in consolidating and propagating traditional culture. It is necessary for teachers to probe into traditional culture that students are familiar with, attract their interest and they will be more willing to learn them. It cannot be neglected that college students in a special stage and their own cultural level have decisive effect that they begin to focus on introspection, self-image and self-development. Intelligence development has reached a peak. Most of them, with quick thought and high acceptability, can develop their logic thought capacity, promote their intelligence and the capacity of analyzing and solving questions after a professional and systemic training.[6] According to college students their own needs and characteristics, traditional culture study is good to promotion of self-image and self-cultivation.

Teachers. Teachers are guarantee of core curriculum implementation. Business English is a new major to most of business English teachers, because they grow into teachers on the basis of mastering foreign language knowledge and foreign language teaching. They are not business English majors, so they have to master business knowledge and even more they must abandon the idea that foreign culture and dominant culture are advanced while our national culture is backward. It is necessary for students that they should not follow foreign culture like sheep, but they find the specialty of their own culture. As business English majors, they have to follow the development of Chinese modernization, inherit and carry forward Chinese fine traditions, show the excellent achievements and absorb the modern elements good to flourishing our national culture.

\section{Conclusion}

Business English provides opportunities for college development, and good luck hard to come by for teachers to strengthen and promote themselves. With the purpose of helping business English graduates work on business affairs in a short time, school courses have their own requirements: colleges should set the business English curricula according to the national standards of business English, which help students solve business problems in the future, business activity and achieve cross-cultural communication in the process of reaching business agreement.

\section{References}

[1] http://teacher.cersp.com/theo/curriculum/200802/4225.html

[2] China's customs agency: China's goods in import and export is expected to stabilize and be better. 2016-4-13 China Securities Journal .http://www.cs.com.cn/(Beijing)

[3] The National Criteria of Teaching Quality for Undergraduate Business English Majors 2015 Ministry of Education

[4] Wang Lifei. the requirements of national criteria for training business English talents and professional construction PPT report .http://wenku.baidu.com/link?url=whPzRKguQuZ-HylGGU9x0kJThyy1M7MS69ntBU1Wsfe LAJwNZB_DaMCilhfEJ3Q1oths_KSdXBw5jKrVU_rtZM-GAyw6PIDL80ka58Sc2z_

[5] A brief analysis of undergraduates' psychological characteristics 2006-11-10 http://muzhi.baidu.com/question/15089988.html 